\title{
EFFECTS OF CALSIUM CARBONAT ON HARDNESS AND WEAR BEHAVIOUR OF BRASS-EPOXY BRAKE LINING PAD
}

\author{
Fajar Nugroho \\ Program Studi Teknik Mesin, Sekolah Tinggi Teknologi Adisutjipto \\ Jl. Janti Blok R Lanud Adisutjipto Yogyakarta.55198 \\ Email : mas_noeg@yahoo.com
}

\begin{abstract}
Brake lining pad is important in driving safety. It must be able to stop the vehicle as quickly as possible. Calcium carbonate is The purpose of this study was to identify the effect of calcium carbonate to the brake brass-epoxy lining pad. Calcium carbonate meet have good physical properties, such as having low porosity and fine particles while brass has a good heat conductor and is corrosion resistant so it is resistant to heat. The tests carried out on brake pads include wear and hardness tests. The results showed that the optimal wear rate in a dry state (40\% calcium carbonate- $20 \%$ brass $40 \%$ epoxy) was $0.0352 \mathrm{~mm}^{2} / \mathrm{kg}$. While the wear rate in wet conditions (20\% calcium carbonate- $40 \%$ brass $-40 \%$ epoxy) was $0.0396 \mathrm{~mm}^{2} / \mathrm{kg}$. The hardness brake lining pad $(20 \%$ calcium carbonate - $40 \%$ brass $-40 \%$ epoxy) was $176.44 \mathrm{~kg} / \mathrm{mm}^{2}$.
\end{abstract}

Keywords: brake pads, composite variation, wearing and hardness

\section{Pendahuluan}

Seiring dengan samkin berkembangnya industri otomotif maka perlu dikembangkan juga material yang mendukung keamanan berkendara. Salah satu keamanan dalam kendaraan adalah sistem pengeremen. Untuk dapat berfungsi denga baik sistem pengereman ini memiliki beberapa bagian salah satunya adalah kampas rem. Bahan kampas rem dapat dibuat dari berbagai material baik yang konvensional maupun material baru yang memiliki tingkat kehandalan baik, tidak berisik dan tidak beracun [1,2,3].

Pengembangan material kampas rem terus dilakukan untuk bisa menggantikan jumlah rem jenis asbestos yang menghasilkan debu yang sangat merugikan kesehatan[2,3]. Berbagai inovasi terus dilakukan untuk mendapatkan jenis material baru yang memenuhi persyaratan baik dari sifat mekanis, sifat fisis maupun persyaratan lainnya [4,5]. Material kampas rem merupakan material yang akan habis karena pemakaian yang diakibatkan adanya gesekan. Gesekan pada kampas rem dengan disk akan menyebabkan debu-debu halus. Kampas rem yang secara umum bahannya terbuat dari asbes tetapi ada juga yang terbuat dari non-asbes. Bahan kampas rem yang terbuat dari asbes sangat membahayakan kesehatan karena dapat mengganggu pencernaan dan banyak negara-negara maju telah menghentikan produksi bahan gesek asbes, karena bahan asbes dapat menyebabkan penyakit kanker pada paru-paru $[5,6,7]$.

Kampas rem yang beredar dipasaaran secara umum terbuat dari bahan asbestos. Kampas rem berbahan asbestos mampu bertahan pada suhu $200^{\circ} \mathrm{C}$ dan debu dari kampas rem ini sangat beracun yang dapat menyebabkan fibrosis (penebalan dan luka gores pada paru-paru), apabila kampas rem ini terkena air maka daya pengeremannya akan terganggu. Kampas rem non asbestos yang mampu bertahan pada temperatur yang lebih tinggi dan tidak menghasilkan debu yang beracun sehingga ramah lingkungan dan apabila terkena air daya pengeremannya masih optimal $[5,6,7,8]$.

Komposit merupakan salah satu bahan alternatif yang dapat digunakan untuk pembuatan kampas rem. Balam perkembangan teknologi komposit mengalami kemajuan 
yang sangat pesat ini dikarenakan keistimewaan sifat yang renewable atau terbarukan dan juga rasio terhadap berat yang tinggi kekuatan, ketahanan terhadap korosi dan lain-lain, sehingga mengurangi konsumsi bahan kimia maupun gangguan lingkaran hidup. Dalam pengembangan material alternatif kampas rem bisa dilakukan dengan menggunakan berbagai bahan alternatif dengan komposisi tertent seperti serbuk kuningan, serbuk aluminium, serbuk kalsium karbonat, resin pengikat dan sebagainya $[9,10,11]$.

\section{Metodologi Penelitian}

Bahan alternatif kampas rem dibuat dari material serbuk kalsium karbonat, serbuk kuningan dan resin epoksi sebagai pengikat. Komposisi kalsium karbonat yang digunakan bervariasi mulai dari 20\%, 30\% dan 40\% fraksi volume. Sedang komposisi dari resin pengikat epoksi tetap sebesar $40 \%$ fraksi volume, sisanya adalah serbuk kuningan. Semua bahan dicampur hingga merata kemudian dicetak dan selanjutnya dilakukan proses kompaksi hingga kering.Setelah diperoleh spesimen uji maka selanjutnya dilakukan pengujian keausan dan pengujian kekerasan untuk melihat kualitas material komposit untuk kampas rem.

\section{Uji Kekerasan}

Uji kekerasan merupakan jenis pengujian yang efektif mengetahui gambaran tentang ketahanan terhadap deformasi atau goresan suatu material. Dalam penelitian ini jenis pengujian yang digunakan adalah uji kekerasan Brinell.

\section{Uji Keausan.}

Keausan dapat didefinisikan sebagai rusaknya permukaan padatan, umumnya melibatkan kehilangan material yang progesif akibat adanya gesekan(friksi) antar permukaan padatan. Keausan bukan merupakan sifat dasar material, melainkan respon material terhadap sistem luar (kontak permukaan). Pengujian keausan dapat dilakukan dengan berbagai macam metode dan teknik, yang semuanya bertujuan untuk mensimulasikan kondisi keausan aktual. Salah satunya adalah metode Ogoshi dimana benda uji memperoleh beban gesek dari cincin yang berputar (revolving disc). Pembebanan gesek ini akan menghasilkan kontak antar permukaan yang berulang-ulang yang pada akhirnya akan mengambil sebagian material pada permukaan benda uji. Besarnya jejak permukaan dari material tergesek itulah yang dijadikan dasar penentuan tingkat keausan pada material. Semakin besar dan dalam jejak keausan maka semakin tinggi volume material yang terkelupas dari benda uji. Uji keausan dilakukan dengan menggunkan metode uji Ogoshi dengan standar benda uji ASTM G 99-95 untuk pengujian keausan

\section{Hasil dan Pembahasan}

\subsection{Hasil Uji Keausan}

Hasil uji keausan dengan metode Ogoshi disajikan pada Gambar 1. Pengujian keausan dilakukan dalam keadaan kering dan basah. 


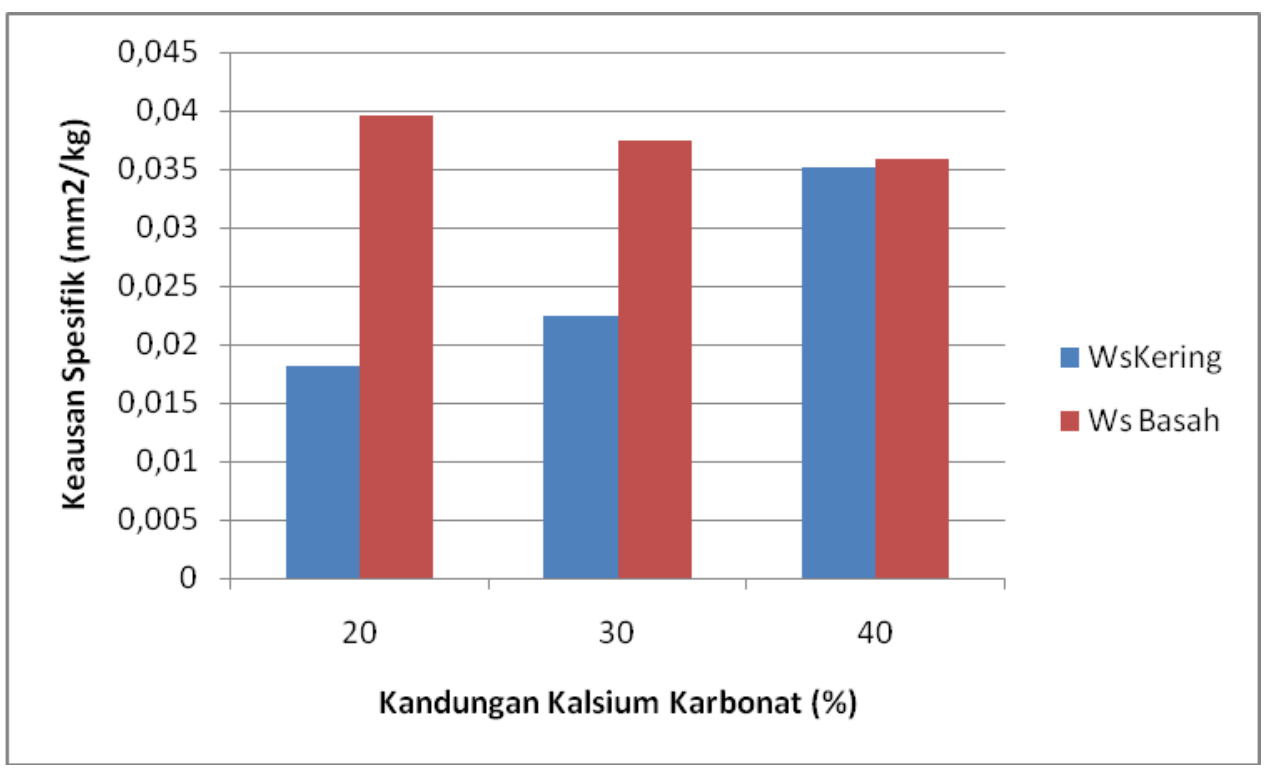

Gambar 1. Hasil Uji Keausan Spesifik

Dari Gambar 1 terlihat bahwa bahan kampas rem yang dibuat dari bahan serbuk kalsium karbonat, serbuk kuningan dan resin epoksi memiliki tingkat keausan spesifik yang berbeda untuk kondisi kering dan basah. Pada pengujian keausan spesifik kering kadar kalsium karbonat mempengaruhi tingkat keausan bahan kampas rem. Semakin besar kandungan kalsium karbonat pada kampas rem maka menyebabkan tingkat keausan spesifiknya akan semakin besar. Pada kandungan kalsium karbonat sebesar 20\% memiliki laju keausan terkecil yaitu sebesar $0,0181 \mathrm{~mm} 2 / \mathrm{kg}$. Laju keausan spesifik pada kondisi kering akan semakin besar seiring dengan meningkatnya kalsium karbonat. Pada komposisi $40 \%$ kalsium karbonat memiliki laju keausan terbesar yaitu $0,0352 \mathrm{~mm} 2 / \mathrm{kg}$. Namun hasil pengujian keausan ogoshi untuk pengujian basah menunjukan kecenderungan yang berbeda dengan hasil pada pengujian keausan metode kering. Pada pengujian keausan basah tidak terjadi perubahan nilai keausan spesifik yang signifikan. Nilai keausan spesifik basah terendah pada bahan rem dengan kandungan kalsium karbonat sebesa 0,0359 $\mathrm{mm} 2 / \mathrm{kg}$ sedangan nilai tertinggi sebsear $0,0396 \mathrm{~mm} / \mathrm{kg}$.

Spesimen bahan kampas rem dengan kandungan $40 \%$ kalsium karbonat memiliki nilai keseimbanganan antara keausan basah maupun keausan kering. Kesemimbangan nilai keausan spesifik dalam keadaan basah dan kering ini mirip dengan nilai keausan spesifik pada bahan kampas rem pabrikan yang ada dipasaran.

\subsection{Hasil Uji Kekerasan}

Gambar 2, merupakan hasil pengujian kekerasan menggunakan brinell dengan komposisi komposisi kalsium karbonat- Serbuk Kuningan-Resin Epoksi; 20\%- 40\%,-40\%, $30 \%-30 \%-40,40 \%-20 \%$ - 40. Seiring dengan bertambahnya serbuk kalsium karbonat dari $20 \%, 30 \%, 40 \%$, dan pengurangan serbuk kuningan dari 40\%, 30\%, 20\% menyebabkan nilai kekerasan juga berubah. Nilaki kekerasan tertinggi diperoleh padaspesimen kampas rem dengan variasi $20 \%$ serbuk kalisium karbonat, dengan nilai kekerasan $176,44 \mathrm{~kg} / \mathrm{mm}^{2}$, dan nilai kekerasan terendah yaitu pada variasi 3 dengan nilai kekerasan $137,47 \mathrm{~kg} / \mathrm{mm}^{2}$, dari hasil pengujian diatas dapat disimpulkan semakin tinggi kadar kalsium karbonat maka akan menyebabkan kekerasan material kampas rem akan semakin turun.

Hubungan antara kekerasan dan keausan kampas rem, berdasarkan sifat untuk keamanan terhadap disk atau piringan kampas rem, bahwa nilai kekerasan dan laju keausan 
tidak menjamin kampas rem memiliki sifat keamanan terhadap piringan atau disk, karena kampas rem harus mengalami kerusakan atau dikorbankan dari pada piringan atau disk pada saat proses pengereman, jika kekerasan tinggi dan laju keausan kecil maka piringan atau disk akan cepat mengalami kerusakan, dan nilai kekerasan kampas rem harus lebih kecil dari pada piringan atau disk.

Nilai lebih dari komposit kampas rem serbuk kalsium karbonat, serbuk kuningan, resin epoxy yaitu untuk material yang dipakai merupakan pemanfaatan dari limbah, dan kampas rem ramah lingkungan serta tidak berbau. Berdasarkan dari pemanfaatan dari bahan bahan diatas nilai yang di hasilkan dari pengujian kekerasan dan keausan hampir mendekati dengan standar kampas rem yang ada dipasaran yaitu $186,95 \mathrm{~kg} / \mathrm{mm}^{2}$.

\section{Kesimpulan}

1. Semakin besar komposisi serbuk kulit telur ayam dan semakin kecil komposisi serbuk kuningan pada kondisi kering maka semakin besar nilai keausannya. nilai keausan ogoshi tertinggi pada kondisi kering pada variasi 3 dengan komposisi $40 \%$ serbuk kulit telur ayam, 20\% serbuk kuningan dan $40 \%$ resin epoxy yaitu 0,0352 $\mathrm{mm} 2 / \mathrm{kg}$.

2. Semakin besar komposisi serbuk kulit telur ayam dan semakin kecil komposisi serbuk kuningan maka semakin kecil nilai kekerasannya, nilai kekerasan brinell tertinggi adalah pada variasi 1 dengan komposisi $20 \%$ serbuk kulit telur ayam, $40 \%$ serbuk kuningan dan $40 \%$ resin epoxy yaitu $176,44 \mathrm{~kg} / \mathrm{mm} 2$

\section{Ucapan Terimakasih}

Penulis mengucapkan terimakasih kepada Adham Ghifari yang telah membantu terlaksananya penelitian ini.

\section{Daftar Pustaka}

[1] Bumi, S.J., (2018). Pengaruh Variasi Komposisi Campuran Serbuk Kulit Telur Ayam dan Serbuk Alumunium Dengan Matrik Epoxy Sebagai Bahan Alternatif Kampas Rem Roda Pesawat Terhadap Kekerasan dan Keausan, Prodi. Teknik Mesin, STT Adisutjipto, Yogyakarta

[2] Ghifari, A., (2019). Pengaruh Variasi Komposisi Campuran Serbuk Kulit Telur Ayam dan Serbuk Kuningan dengan Matrik Epoxy sebagai Bahan Alternatif Kampas terhadap Keausan dan Kekerasan, Prodi. Teknik Mesin, STT Adisutjipto, Yogyakarta

[3] Kiswiranti, D., Sugianto, N. Hindarto, Sutikno. (2009). Pemanfaatan Serbuk Tempurung Kelapa sebagai Alternatif Serat Penguat Bahan Friksi Non-Asbes Pada Kampas Rem Sepeda Motor. Jurnal Pendidikan Fisika Indonesia. Vol 5. Hlm. 62-66.

[4] Oroh, Jonathan, Frans P. Sappu, Romels Lumintang. (2013). Analisis Sifat Mekanik Material Komposit dan Serat Sabut Kelapa. Teknik Mesin, Universitas Sam Ratulangi Manado.

[5] Purboputro, Pramuko Ilmu. (2012). Pengembangan Kampas Rem Sepeda Motor Dari Komposit Serat Bambu, Fiber Glass, Serbuk Aluminium dengan Pengikat Resin Polyester Terhadap Ketahanan Aus dan Karakteristik Pengeremannya. Prosiding Seminar Nasional Aplikasi Sains \& Teknologi (SNAST) Periode III. ISSN: 1979-911X.

[6] Qurohman, M. T., Syarifudin. (2016). Analisa Beban Pengereman Terhadap Kualitas Kampas Rem Tromol Mobil Dengan Metode Oghosi. Jurnal Matematika Vol. 19, No.1, hlm. $8-12$.

[7] Santoso, S., Estriyanto, Y., Wijayanto, D.S., (2013). Studi Pemanfaatan Campuran Serbuk Tempurung Kelapa-Aluminium Sebagai Material Alternatif Kampas Rem 
Sepeda Motor Non-Asbestos. Pendidikan Teknik Mesin, Jurusan Pendidikan Teknik dan Kejuruan, FKIP, UNS.

[8] Supriyanto, Bambang W. Febriantoko. (2016). Pengujian Performa Kampas Rem Non Asbes Variasi Calcium Carbonate dengan Perekat Phenolic Resin . Teknik Mesin Universitas Muhammadiyah Surakarta.

[9] Syawaluddin, Hindarto. N, Marwoto. P, \& Rustad. S. (2009). Pembuatan Bahan Gesek Kampas Rem Menggunakan Serbuk Tempurung Kelapa sebagai Pemodifikasi Gesek. Jurnal Fakultas Matematika dan Ilmu Pengetahuan Alam. Universitas Negeri Semarang.

[10] Sutikno. (2008). Pengaruh Komposisi Serbuk Tempurung Kelapa terhadap Sifat-Sifat Fisik dan Mekanik Bahan Gesek Non Asbes untuk Aplikasi Kampas Rem Sepeda Motor. Jurnal Ilmiah Populer dan Teknologi Terapan, Vol. 6, No. 2, hlm: 893-904

[11] Wahyudi, Tri. (2010). Pembuatan dan Pengujian Sifat Fisis dan Mekanis Kampas Rem dengan Bahan Dasar Serbuk Al, Arang Tempurung Kelapa dengan Matriks Epoxy. Surakarta : Laporan Tugas Akhir Fakultas Teknik Mesin Universitas Muhammadiyah Surakarta. 
Fajar Nugroho 